\title{
SLABÉ JEDNANÍ Od etiky k politice a zase zpátky
}

Pomocí pojmu slabého jednání se pokoušíme navázat na diskuse o vztahu mezi jednáním svobodného politického subjektu a jeho závislostí na druhých a na okolnostech, bez nichž by jeho jednání nebylo možné. Důraz na to, že jde o jednání v slabém smyslu, je motivován snahou o to překonat schizma, jež je hluboce zaryto v západním politickém myšlení a jež proti sobě klade jednání jako svobodnou aktivitu průhledné a sebezakládající instance a závislost na podpoře druhých a okolí. Prostřednictvím pojmu slabého jednání pak chceme odmítnout tuto neslučitelnost jednání a závislosti na druhých tím, že do samotného výkonu svobody politického subjektu zahrneme etické uvědomění si možného násilí svých vlastních činů ve vztahu $\mathrm{k}$ těm životům, $\mathrm{k}$ nimž je subjekt poután, včetně těch, které nezná a nikdy nepozná. V následujícím textu se tímto tématem budeme zabývat z hlediska dvou otázek: kromě problému, jak eticky oslabit pojem politického jednání (tj. jak uchopit politiku z hlediska etiky), se budeme zabývat tím, jak by se etika zranitelnosti mohla stát zdrojem nejen kritiky politiky, ale také konkrétního jednání. Jako extrémní případ vyhrocenosti této dichotomie mezi politikou a etikou a jako půda, $\mathrm{z}$ níž by bylo možné tuto dichotomii překonat, nám přitom poslouží filosofie Emmanuela Levinase.

Je však vůbec možné myslet politické jednání na půdorysu Levinasovy etiky radikální jinakosti? Levinasovi čtenáři dobře znají hiát, jenž v rámci jeho myšlení ostře odděluje sféru etiky, kterou charakterizuje nekonečná odpovědnost za druhého, a sféru spravedlnosti - konečného politického jednání, které vždy již zahrnuje třetího, a nutně tedy primární etické pouto k druhému vylučuje. Co se týká obsahu této nekonečné etické odpovědnosti, je jím odpověd’ na zranitelnost druhého, kterou Levinas nazývá jeho tváří. Jedním z důsledků onoho hiátu, který může u filosofa hyperbolické odpovědnosti za druhého působit překvapivě, je pak to, že v politické sféře jakožto sféře srovnávání a rovnosti lidí je jejich tvář smazána či uzávorkována. Tento paradox absence tváře $\mathrm{v}$ politice, jenž je ve skutečnosti konsistentním dodržováním zmíněného hiátu mezi etikou a politikou, je dobře vidět $v$ hojně kritizované pasáži z rozhovoru se Salomonem Malkou, kde Levinas neprrímo upírá tvář Palestincům. Na otázku, zda pro Izraelce nepředstavuje „druhého“ (l'autre) především Palestinec, odpovídá Levinas nepřímo záporně: v případě, že jeden 
z bližních (le prochain) napadne jiného, se etika stává politikou a etika „tváře“ (a zákaz zabití, jenž je jejím obsahem) neplatí absolutně: máme povinnost svého bližního či své bližní (v tomto př́ípadě členy svého národa) bránit a to i za cenu použití armády a zbraní. ${ }^{1}$ Jinak řečeno, třetí přináší kontradikci do duálního a jednosměrného etického vztahu k druhému, a tím zakládá politiku, která je v rozporu s prvotní etickou sférou, byt' je její založení samo eticky nutné. Palestinec „bez tváře“ tudíž neznamená, že by Levinas protiřečil svému pojetí etiky. Je spíše smutným př́kladem toho, kam vede striktní oddělování etiky a politiky: v tomto případě ústí v jednoznačně nacionalistické a komunitaristické postoje u filosofa druhého. Naše hledání slabého jednání v tomto smyslu kriticky navazuje na Levinase: jak uchovat jádro Levinasovy filosofie - jeho etiku zranitelnosti - a zároveň, navzdory jeho pojetí politiky, přenést tvář právě i do politické oblasti? ${ }^{2}$ Myslet slabé jednání z Levinase a jemu navzdory tedy za prvé znamená zpochybnit hiát oddělující tvář od politiky.

Zajisté by bylo možné provést $\mathrm{v}$ rámci Levinasova myšlení samého kritiku jeho př́kladu s izraelsko-palestinským konfliktem a to právě ve jménu oné radikálně jiné sféry, jíž je etika: bylo by možné zdůraznit, že i válečný nepřítel má tvář. $V$ tom okamžiku bychom se však ocitli vně politiky, přičemž je jen velmi těžko představitelné, jak by tento čistě etický moment mohl jakkoli nabourat onu politickou rovinu, $v$ tomto případě rovinu nacionálního či komunitárního konfliktu. Na tuto veskrze abstraktní povahu Levinasovy koncepce politiky již poukázal argentinský filosof Enrique Dussel. ${ }^{3}$ Podle něj tato koncepce nenabízí konkrétní způsoby, jak vybudovat etičtější politiku. Jinými slovy, Levinasovi se nedaří artikulovat pozitivní architekturu konkrétních zprostředkování mezi etikou a politikou. Aby bylo možné na základě etiky zranitelnosti vůbec jednat, a vyhnout se tak výše naznačeným aporiím, je totiž také třeba, abychom, kromě toho, že nakrmíme hladového, zjednáme spravedlnost pro vdovu či nabídneme pohostinnost cizinci, také porozuměli konkrétní historické a sociální existenci těchto bližních. Jen takové porozumění umožní nalézt politická zprostř̌edkování, která by například chudým umožnila osvobodit se od jejich chudoby. Myslet slabé jednání

1 Srv. E. Levinas, Israël, éthique et politique, entretiens avec S. Malka (avec Alain Finkielkraut), in: Les Nouveaux cahiers, 71, 1983, str. 4.

2 Ucelenější itinerář tohoto hledání „slabého jednání“ čtenář nalezne v naší knize: J. Bierhanzl, L'action faible: De l'éthique à la politique, Paris 2018.

3 E. Dussel, Lo político en Levinas (Hacia una filosofía política crítica), in: Signos Filosóficos, 9, 2003, str. 111-132. 
z Levinase a jemu navzdory tedy za druhé znamená vnést do hry jiné filosofické tradice, než je fenomenologie: na mysli máme zejména myšlení Michela Foucaulta a Karla Marxe. Zdaleka nejkomplexněji se však podařilo artikulovat Levinasovu etiku zranitelnosti a politické jednání Judith Butlerové, a to zejména v jejích pozdních textech o etice a politice nezajištěnosti života.

Butlerová přesvědčivě ukazuje, že Levinasova etika zranitelnosti - navzdory jeho vlastnímu pojetí politiky - umožnuje myslet to, co zde označujeme jako slabé jednání, avšak pouze tehdy, pokud samo jádro jeho etiky, strukturu oslovení druhým, podrobíme určité kulturní transpozici. V tomto smyslu Butlerová navazuje na ten typ kritiky, který reprezentují práce postkolonialisty Dussela a potvrzuje naši hypotézu, podle níž myslet slabé jednání v návaznosti na Levinase znamená otevřít jeho fenomenologii sociálním filosofiím. Transpozice Levinasova vztahového rámce, jakou navrhuje Butlerová, je přitom podle nás trojí4.

Butlerová za prvé problematizuje vztah tváře a jevení. V Rámcích války autorka přenáší Levinasovu etiku do vizuální kultury, přičemž se s Levinasovým popisem zkušenosti tváře jako „protržení smyslovosti““ rozchází v tom, že situuje tvář do oblasti toho, co se jeví. ${ }^{5}$ Radikalita Levinasova přístupu spočívá právě v tom, že lze v rámci jeho koncepce jen stěží hovořit o fenomenologii tváře: „tvář ve specifickém slova smyslu je právě to, co nelze zredukovat na percepci,“ píše Levinas v Etice a nekonečnu. ${ }^{6}$ Butlerová naproti tomu ukazuje, jak je etický požadavek ve skutečnosti vždy zprostředkován našimi smysly, avšak pouze za předpokladu, že společenská organizace těchto smyslů nevylučuje tvář z oblasti toho, co se jeví. Když tvář zahrneme do sféry jevení, jak to činí Butlerová, jistě ztrácíme určitou fenomenologickou radikalitu Levinasových analýz (která paradoxně spočívá $\mathrm{v}$ tom, že zdůrazňují radikální přesahování fenoménu). Touto fenomenalizací tváře však zase získáváme vhled do konkrétních sociálně historických způsobů produkce a vymazávání tváře, které také etickému subjektu umožňují hledat konkrétní způsoby

4 K podrobnějšímu předvedení recepce a kulturní transpozice Levinasova etického rámce v pozdních pracích Judith Butlerové, viz náš text: J. Bierhanzl, Tvář a její politické rámy. Emmanuel Levinas a Judith Butlerová, in: O. Sikora - J. Sirovátka (vyd.), Levinas v konfrontaci, prripraveno k vydání.

5 E. Levinas, Totalita a nekonečno. Esej o exterioritě, přel. M. Petříček - J. Sokol, Praha 2007, str. 174.

6 Týž, Etika a nekonečno, přel. V. Dvořáková - M. Rejchrt, Praha 2009, str. 208. 
odpovídání a jednání (jež lze jen těžko odvozovat z ahistorické výše, kam je situována tvár̆ u Levinase).

Za druhé, Butlerová odjímá etickému subjektu tragičnost individuální nezastupitelnosti jeho rozhodnutí tím, že ukazuje, jak je tento subjekt vždy již spoluutvářen jinými, pro jejichž působení na sebe sama se ne vždy sám rozhodl. Butlerová s Levinasem souhlasí v tom, že etiku primárně charakterizuje struktura oslovení, v níž jsme právě my vyzýváni, abychom určitým způsobem odpovídali. Individuaci tohoto „my“ však autorka chápe méně exkluzivně, tj. ,jä“ podle ní nenese veškerou tíhu odpovědnosti na svých bedrech, nýbrž svou odpovědnost vždy již sdílí s těmi, kteří jej spoluutvářejí, aniž by si toho bylo plně vědomo: tím se jí daří vyhnout levinasovským aporiím. Slabé jednání potom již není problémem individuálního etického subjektu, jenž ve svých rozhodnutích nesmí vylučovat jinakost druhého, jehož každé rozhodnutí však zároveň nutně znamená jisté vyloučení, ale má vždy již kolektivní dimenzi: ,Je-li požadavek registrován, neodhaluje mne ani tak jako ,ego', ale spíše jako bytost svázanou s druhými neoddělitelným a nezvratným způsobem, jako bytost existující v zobecněné podmínce nezajištěnosti a vzájemné závislosti, hnanou afekty a tvořenou těmi, jejichž působení na mě jsem si nikdy nevybrala.“7

Za třetí pak Butlerová v prvotní asymetri (tj. v rámci vztahu $\mathrm{k}$ jinakosti), jež charakterizuje etiku, uvažuje reciprocitu, bez níž si lze jen těžko představit zrod politického subjektu. Slovy jednoho z komentátorů: „Přestože jak Butlerová, tak Lévinas zdůrazňují určitou asymetrii, jinakost, která předchází identitě, u Butlerové je tento primát jinakosti učiněn principem reciprocity. “8 Butlerová přitom činí z prvotní asymetrie princip reciprocity či vzájemnosti hned dvojím způsobem:

Nejprve tím, že do našich etických vazeb zahrne naši začleněnost do vztahů s prvotními pečovateli (tj. vztáhne etický subjekt k jeho dětství, čímž jeho perspektivu dospělého významným způsobem decentruje). Soubor vztahů a procesů, jimiž jsme byli začleněni do světa našich prvotních pečovatelů, přitom charakterizuje určité nevědění o nás samých. ${ }^{9}$ Jistá neprůhlednost etického subjektu vůči sobě samému zde podle Butlerové vychází z toho, že ,,je považován za relační bytost, jejíž

7 J. Butlerová, Rámce války. Za které životy netruchlíme?, přel. A. Handl, Praha 2013, str. 153.

8 J. Fulka, Etika po smrti subjektu. J. Derrida a J. Butlerová,in: J. Jirsa et al., Přístupy k etice, III, Praha 2016, str. 286, pozn. 68.

9 Srv. J. Butlerová, Giving an Account of Oneself, Fordham 2005, str. 59. 
rané a primární vztahy nejsou vždy dosažitelné vědomému poznání." ${ }^{10}$ Toto nevědění ohledně nás samých a vztahů, které nás formovaly, aniž bychom se pro to mohli rozhodnout, však sdílíme všichni. Tato zkušenost jinakosti v podobě částečné slepoty ohledně nás samých je tedy principem etiky reciprocity.

Dále Butlerová činí z asymetrie reciprocitu tím, že ukazuje, že schopnost být osloven jinakostí předpokládá nezajištěný tělesný život, který se rovněž týká každého: at' chceme či nechceme, život každého z nás je podmíněn vzájemnou závislostí a nezajištěností života obecně. Slovy J. Butlerové: „Nezajištěnost implikuje život ve společnosti, tedy skutečnost, že život každého jedince je do jisté míry v rukou druhých." ${ }^{11}$

Tato trojí kulturní transpozice vztahového rámce Levinasovy etiky je podle nás třetí nutnou podmínkou slabého jednání a jasným dokladem toho, že myslet toto jednání z Levinase a jemu navzdory znamená, kromě zpochybnění hiátu mezi etikou a politikou a otevření jeho fenomenologie sociálním filosofiím, také podstatnou revizi samotného jádra jeho etického myšlení: revidována je sama asymetrická struktura nezjevného oslovení dospělého individuálního etického subjektu historicky a sociálně neuchopitelným druhým.

Jan Bierhanzl

10 Tamt., str. 20.

11 J. Butlerová, Rámce války, str. 19-20. 